\title{
DAMPAK PENGGUNAAN SMARTPHONE DI LINGKUNGAN SEKOLAH TERHADAP PRESTASI BELAJAR SISWA
}

\section{Effect of Smartphone Use in School Environments on Student Learning Achievements}

\author{
${ }^{1}$ Asmurti, ${ }^{2}$ Andi Alimuddin Unde, ${ }^{3}$ Tawany Rahamma \\ ${ }^{1}$ Jurusan Ilmu Komunikasi Fakultas Ilmu Sosial dan Imu politik Universitas Hasanuddin Makassar (Email: \\ asmurtilaea@gmail.com) \\ ${ }^{2}$ Jurusan Ilmu Komunikasi Fakultas Ilmu Sosial dan Imu politik Universitas Hasanuddin Makassar (Email: \\ undealimuddin@yahoo.co.id) \\ ${ }^{3}$ Jurusan Ilmu Komunikasi, Fakultas Ilmu Sosial dan Ilmu Politik, Universitas Hasanuddin, Makassar
}

\begin{abstract}
ABSTRAK
Penelitian ini bertujuan untuk (1) mengetahui penggunaan smartphone di lingkungan sekolah di SMAN Provinsi Sulawesi Tenggara, (2) mengetahui prestasi belajar siswa di SMAN Provinsi Sulawesi Tenggara, dan (3) mengetahui pengaruh penggunaan smartphone di lingkungan sekolah terhadap prestasi belajar siswa di SMAN Provinsi Sulawesi Tenggara. Penelitian ini menggunakan pendekatan kuantitatif dengan metode penelitian ex-post facto terhadap populasi penelitian yang berasal dari siswa kelas XI SMAN 1 Kendari, SMAN 4 Kendari, SMAN 1 Kulisusu dan SMAN 2 Kulisusu. Sampel yang diambil berjumlah 647 orang dengan metode simple random sampling. Teknik analisis regresi linear sederhana digunakan untuk melihat hubungan penggunaan smartphone di lingkungan sekolah terhadap prestasi belajar siswa dan uji $t$ untuk membandingkan prestasi belajar siswa yang mengizinkan dan tak mengizinkan penggunaan smartphone di lingkungan sekolah. Hasil penelitian menunjukkan bahwa (1) penggunaan smartphone di lingkungan sekolah cukup tinggi; (2) prestasi belajar siswa untuk sekolah yang mengizinkan menggunakan smartphone lebih tinggi dibandingkan tingkat prestasi pada sekolah yang tidak mengizinkan; dan (3) terdapat pengaruh yang signifikan antara penggunaan smartphone terhadap peningkatan prestasi belajar siswa di lingkungan sekolah.
\end{abstract}

Kata Kunci: penggunaan smartphone, prestasi belajar

\begin{abstract}
This study aims to (1) determine the use of smartphones in a school environment in Southeast Sulawesi Province Senior High School; (2) find out the learning achievement of students in Southeast Sulawesi Province Senior High School; and (3) find out the effect of smartphone use in the school environment on student achievement in provincial high schools Southeast Sulawesi. This study uses a quantitative approach with ex-post facto research methods on the study population from students of class XI SMAN 1 Kendari, SMAN 4 Kendari, SMAN 1 Kulisusu and SMAN 2 Kulisusu. Samples taken were 647 people with simple random sampling method. Simple linear regression analysis technique is used to see the relationship of smartphone usage in the school environment to student learning achievement and test to compare student achievement that allows and permits the use of smartphones in the school environment. The results showed that (1) the use of smartphones in the school environment was quite high; (2) student learning achievement for schools that permit using smartphones is higher than the level of achievement in schools that do not allow using smartphones in school environments; and (3) there is a significant influence between smartphone usage on improving student learning achievement in the school environment.
\end{abstract}

Keywords: Smartphone usage, learning achievement 


\section{PENDAHULUAN}

Penggunan smartphone telah meluas hingga ke berbagai macam kalangan, tidak hanya digunakan oleh orang dewasa ataupun orang tua. Akan tetapi, sudah meluas hingga ke peserta didik yang kini telah menggunakannya. Smartphone digunakan tidak hanya untuk berkomunikasi dan berkirim pesan, tetapi juga sudah meluas hingga mengakses internet, kirim e-mail, dan bahkan hingga penggunaan media sosial pada kalangan peserta didik.

Menurut Istiyanto (2013) menyatakan bahwa "saat ini kita telah memasuki masa interaksi antara manusia dengan komputer bersifat natural atau biasa disebut ubicom yang didukung beberapa faktor. Pertama, dukungan ketersediaan jaringan infrastruktur nirkabel dengan cakupan yang luas untuk komunikasi data atau komunikasi audio dan video digital. Kedua, teknologi mikroprosesor yang semakin canggih. Ketiga, faktor gaya hidup pengguna yang sekarang ini mulai bergantung pada perangkat mobile sebagai alat komunikasi di jaringan sosial, akses layanan e-mail, chatting, atau telekonferensi”.

Penggunaan smartphone dikalangan siswa dilandasi oleh beberapa alasan, seperti hanya ingin mengikuti trend, atau untuk lebih aktif di media sosial (facebook, whats app, instagram, bbm, line dan lain sebagainya), mencari informasi mengenai hobi dan sebagainya serta ada juga siswa yang memanfaatkan smartphone sebagai sumber belajar, mencari tambahan materi pelajaran, membagi informasi kepada teman sekelas mengenai tugas yang diberikan.

Melihat aktifitas remaja dalam menggunakan smartphone, berbagai kebijakan diterapkan oleh pihak sekolah kepada siswa atau pelajarnya, diantaranya ada sekolah yang mengizinkan siswa menggunakan smartphone dan ada juga pihak sekolah yang tidak mengizinkan siswa menggunakan smartphone di lingkungan sekolah. Adapun alasan pihak sekolah yang mengizinkan siswa untuk menggunakan smartphone di lingkungan sekolah adalah kelebihan smartphone yang bisa dengan cepat mengakses informasi yang dibutuhkan, bahkan sebagian guru kelas memperbolehkan siswa menggunakan smartphone saat proses belajar mengajar berlangsung dengan alasan dapat menunjang proses pembelajaran. Sementara alasan sekolah tidak mengizinkan siswa menggunakan smartphone di lingkungan sekolah, melihat dampak buruk dari penggunaan smartphone yang bisa merusak moral siswa yang dengan mudahnya mengakses situs-situs pornografi dan menjadi korban tindak kejahatan di dunia maya.

Penelitian ini bertujuan untuk (1) mengetahui penggunaan smartphone di lingkungan sekolah SMAN Provinsi Sulawesi Tenggara. (2) mengetahui prestasi belajar siswa di SMAN Provinsi Sulawesi Tenggara. (3) mengetahui pengaruh penggunaan smartphone di Lingkungan sekolah terhadap prestasi belajar siswa di SMAN Provinsi Sulawesi Tenggara.

\section{BAHAN DAN METODE PENELITIAN}

\section{Rancangan Penelitian}

Sukardi (2012) bahwa penelitian ex-post facto merupakan penelitian yang berhubungan dengan variabel yang telah terjadi dan tidak perlu memberikan perlakuan terhadap variabel yang diteliti. Sehingga, dalam penelitian expost facto, peneliti tidak memberikan suatu perlakuan untuk variabel yang akan diteliti. Penelitian ini, hubungan sebab akibat antar variabel disajikan sesuai dengan fakta yang ada yang diperoleh dari data yang telah terkumpul.

\section{Populasi dan sampel penelitian}

Adapun Populasi dalam penelitian ini adalah siswa kelas XI (IPA 1,2,3 dan IPS 1,2,3) di SMAN 1 dan 4 Kota Kendari serta SMAN 1 dan 2 Kulisusu Kabupaten Buton Utara, Sulawesi Tenggara. Penentuan jumlah sampel yang digunakan peneliti ialah melalui rumus Slovin, sebagai berikut:

$$
n=\frac{N}{1+N e^{2}}
$$

Dimana:

$$
\begin{aligned}
& \mathrm{n}=\text { ukuran sampel } \\
& \mathrm{N}=\text { ukuran populasi } \\
& \mathrm{e}=\text { tingkat kesalahan }(5 \%)
\end{aligned}
$$

Alasan menggunakan tingkat kesalahan 5\% karena penelitian ini merupakan penelitian sosial yang subjeknya dinamis. Sehingga, hasil penelitian ini nantinya berada pada interval kepercayaan 95\%. Maka, jumlah sampel dalam penelitian ini adalah: 


$$
\begin{aligned}
& n_{S M A 1 \text { Kendari }}=\frac{308}{308 \times 0.05^{2}+1}=\mathbf{1 7 4} \\
& n_{S M A \text { 4 Kendari }}=\frac{296}{296 \times 0.05^{2}+1}=\mathbf{1 7 0} \\
& n_{S M A 1 \text { Kulisusu }}=\frac{296}{296 \times 0.05^{2}+1}=\mathbf{1 7 0} \\
& n_{S M A 2 \text { Kulisusu }}=\frac{199}{199 \times 0.05^{2}+1}=\mathbf{1 3 3}
\end{aligned}
$$

Jadi, total sampel dalam penelitian ini adalah 647 siswa. Teknik sampel yang digunakan adalah jenis metode simple random sampling. Sampel mewakili sekolah yang mengizinkan dan tidak mengizinkan penggunaan smartphone. Setelah mendapatkan sekolah terpilih maka dilanjutkan dengan memberikan kuesioner kepada siswa.

\section{Metode Pengumpulan Data}

Adapun metode pengumpulan data yang digunakan adalah sebagai berikut:

Kuisioner (Angket) adalah sejumlah pertanyaan tertulis yang digunakan untuk memperoleh informasi dari responden dalam arti laporan tentang pribadinya atau hal-hal yang ia ketahui (Arikunto, 2006). Dalam penelitian ini, responden akan diberikan angket berupa angket tertutup yang telah disediakan alternatif jawaban oleh penulis. Sehingga, memudahkan responden dalam memberi jawaban.

Dokumentasi, merupakan teknik pengumpulan data dari dokumen berupa laporan, buku-buku, foto-foto, literatur maupun dokumen yang terkait dengan penelitian.

\section{Analisis Data}

Data yang terkumpul selanjutnya diolah dan dianalisis, proses analisis data menggunakan analisis regresi linear sederhana. Menurut Mustikoweni (2002), regresi ditujukan untuk mencari bentuk hubungan dua variabel atau lebih dalam bentuk fungsi atau persamaan. Untuk meriset apakah memang ada dampak penggunaan smartphone di lingkungan sekolah terhadap prestasi belajar siswa (sebab akibat), maka digunakan regresi model regresi liner sederhana. Adapun rumusnya sebagai berikut:

$$
Y=a+B x
$$

$\mathrm{Y}=$ Variabel tidak bebas (Prestasi

belajar siswa)

$\mathrm{x}=$ Variabel bebas (Penggunaan

smartphone)

$\mathrm{a}=$ Nilai intercept (konstan) atau

harga $\mathrm{X}$ bila $\mathrm{Y}=0$

$\mathrm{B}=$ Koefisien regresi, yaitu angka peningkatan atau penurunan variabel dependen yang didasarkan pada variabel independen.

Untuk membandingkan prestasi belajar antara sekolah yang mengizinkan dan tidak mengizinkan menggunakan smartphone maka digunakan uji t independen.

\section{HASIL PENELITIAN DAN PEMBAHASAN}

\section{Hasil}

\section{Intensitas Penggunaan Smartphone}

Tabel 4.1 menunjukkan bahwa jumlah data intensitas penggunaan smartphone yang diproses adalah 647 siswa. Nilai rata-rata intensitas penggunaan smartphone 35,88. Median menunjukkan titik tengah data berada pada angka 37. Mode atau angka yang paling sering muncul dalam intensitas penggunaan smartphone 35. Sementara untuk nilai Range atau selisih antara nilai minimum dan maksimum 41, dengan nilai maximum sebesar 52 dan nilai minimum 11 .

Tabel 4.2 menunjukkan bahwa berdasarkan variabel kepemilikan smartphone lebih banyak terdapat pada responden dengan kategori memiliki smartphone dan jaringan yaitu sebesar 77,3\% (500 orang).

Tabel 4.3 menunjukkan bahwa berdasarkan variabel intensitas penggunaan smartphone lebih banyak terdapat pada kategori rendah yaitu sebesar 56,9\% (368 orang).

Tabel 4.4 menunjukkan bahwa kelompok sekolah yang mengizinkan dan tidak mengizinkan penggunaan smartphone, lebih banyak terdapat pada sekolah yang mengizinkan yaitu sebesar 53\% (343 orang).

Prestasi Belajar Siswa

Dimana: 
Adapun gambaran Prestasi Belajar Siswa dapat dilihat dari tabel berikut:

Tabel diatas menunjukkan bahwa jumlah data prestasi belajar siswa yang diproses adalah 647 siswa. Nilai rata-rata prestasi belajar siswa 85. Median menunjukkan titik tengah data berada pada angka 85. Mode atau angka yang paling sering muncul dalam prestasi belajar siswa 90. Sementara untuk nilai Range atau selisih antara nilai minimum dan maksimum 33, dengan nilai maximum sebesar 94 dan nilai minimum 61.

Berdasarkan tabel 4.6. menunjukkan bahwa siswa yang memiliki tingkat prestasi yang tinggi lebih banyak yaitu sebesar 58,9\% (381 orang) dibandingkan dengan yang rendah sebesar $41,1 \%$ (266 orang).

Hubungan Intensitas Penggunaan Smartphone dengan Hasil Belajar Siswa

Untuk melihat hubungan Intensitas penggunaan smartphone dengan hasil belajar siswa digunakan Analisis regresi linear sederhana dengan menggunakan aplikasi SPPS.

Nilai koefisien determinasi atau $\mathrm{R}$ square $(R 2)=0,168$. Nilai ini menunjukkan bahwa pengaruh variabel intensitas terhadap prestasi belajar siswa adalah sebesar 16,8\%.

Pada tabel 4.8 diperoleh nilai $\mathrm{F}$-hitung sebesar 129, 851 dengan nilai $p=0,000$. Karena nilai $\mathrm{p}<0,05$, maka model persamaaan yang diperoleh adalah baik (good of fit).

Tabel 4.9 diperoleh nilai Unstandardized Coefficients $(\mathrm{Bo})=0,454$ dan nilai $(\mathrm{B} 1)=0,436$, sehingga model regresi yang diperoleh adalah:

$$
\begin{gathered}
Y=a+B x \\
Y=0,454+0,436 \text { (intensitas) } \\
\text { Prestasi }=0,454+04,36 \text { (intensitas) }
\end{gathered}
$$

Besarnya pengaruh intensitas penggunaan smartphone terhadap prestasi belajar siswa $=0,436$ dengan nilai $\mathrm{p}=0,000$. Karena nilai $\mathrm{p}=0,000<0,05$, maka dapat disimpulkan bahwa ada pengaruh intensitas terhadap prestasi siswa. Dari model ini diperoleh koefisien regresi bernilai positif yang artinya semakin tinggi intensitas penggunaan smartphone maka akan semakin meningkat prestasi belajar siswa.

Perbandingan Prestasi Belajar Siswa antara Sekolah yang Mengizinkan dan tidak Mengizinkan Menggunakan smartphone di Lingkungan Sekolah (Uji T)
Untuk melihat perbandingan prestasi belajar siswa antara sekolah yang mengizinkan dan tidak mengizinkan siswa menggunakan smartphone di lingkungan sekolah digunakan Analisis Uji T dengan aplikasi SPPS.

Hasil perhitungan tersebut menunjukkan bahwa nilai $\mathrm{F}$ hitung adalah 116,363 dengan nilai $\mathrm{p}=0,000<0,05$ maka disimpulkan bahwa variansi kedua kelompok heterogen. Nilai $p$ yang diperoleh $=0,000<0,05$ maka Ho ditolak, artinya prestasi belajar siswa sekolah yang mengizinkan menggunakan smartphone lebih tinggi dibandingkan prestasi belajar siswa sekolah yang tidak mengizinkan menggunakan smartphone di lingkungan sekolah.

\section{Pembahasan}

Penggunaan smartphone di lingkungan sekolah

Hasil penelitian diperoleh bahwa sebagian besar responden kurang aktif menggunakan smartphone. Hal ini dapat dilihat dari intensitas penggunaan smartphone yang dikategorikan rendah sebanyak 368 siswa $(56,9 \%)$ dari total responden 647 siswa (sekolah yang mengizinkan menggunakan smartphone sebanyak 343 siswa dan sekolah yang tidak mengizinkan menggunakan smartphone sebanyak 304 siswa).

Sejalan dengan Model uses and gratification menunjukkan bahwa yang menjadi permasalahan utama bukanlah bagaimana media mengubah sikap dan perilaku khalayak, melainkan bagaimana media memenuhi kebutuhan pribadi dan sosial khalayak. Jadi, bobotnya yaitu pada khalayak yang aktif, yang sengaja menggunakan media untuk mencapai tujuan khusus. (Effendy, 1993).

\section{Prestasi belajar siswa}

Dari hasil penelitian diperoleh hasil bahwa tingkat prestasi belajar siswa sekolah yang mengizinkan menggunakan smartphone lebih tinggi dibandingkan tingkat prestasi sekolah yang tidak mengizinkan menggunakan smartphone di lingkungan sekolah.

Menurut Ahmadi (1998) salah satu faktor yang menunjang keberhasilan dalam proses belajar adalah tersedianya sumber belajar yang memadai. Sumber belajar yang 
memadai itu adalah berupa media/alat bantu belajar yang merupakan semua alat yang dapat digunakan untuk membantu siswa dalam menunjang pembelajaran sehingga pelajaran akan lebih menarik minat, mudah dipahami, hemat waktu dalam pembelajaran dan hasil yang diperoleh lebih maksimal. Pada saat ini sumber-sumber belajar dapat diperoleh dari dunia maya. Perkembangan internet, smartphone maupun media sosial sangat besar pengaruhnya terhadap prestasi belajar siswa.

\section{Pengaruh Penggunaan smartphone di} Lingkungan Sekolah terhadap Prestasi Belajar Siswa

Hasil penelitian menunjukan nilai koefisien regresi bernilai positif. Artinya, semakin tinggi intensitas dalam menggunakan smartphone, semakin tinggi prestasi belajar siswa. Sebaliknya, semakin rendah intensitas penggunaan smartphone, semakin rendah pula prestasi belajar siswa.

Hal ini sejalan dengan penelitian sebelumnya yang dilakukan oleh Jauhar, dkk (2015) yang menyatakan bahwa Intensitas penggunaan smartphone memiliki pengaruh positif dan signifikan terhadap prestasi belajar pada siswa SMP Negeri 5 Pati. Semakin tinggi intensitas penggunaan smartphone maka semakin tinggi pula prestasi belajar anak.

Dengan dizinkan siswa menggunakan smartphone di lingkungan sekolah siswa dengan bebas mengakses informasi dalam memenuhi kebutuhan yang mereka inginkan. Beragam penggunaan ini mencerminkan asumsi dasar teori Uses and Gratifications. Katz, Blumler dalam Rakhmat (1991) merumuskan asumsi dasar teori ini:

Khalayak dianggap aktif, artinya sebagian penting dari penggunaan media massa diasumsikan mempunyai tujuan.

Dalam proses komunikasi massa banyak inisiatif untuk mengaitkan pemuasan kebutuhan dengan pemilihan media terletak pada anggota khalayak.

Media massa harus bersaing dengan sumber-sumber lain untuk memuaskan kebutuhannya. Kebutuhan yang dipenuhi media hanyalah bagian dari rentangan kebutuhan manusia yang lebih luas. Bagaimana kebutuhan ini terpenuhi melalui konsumsi media, sangat tergantung kepada perilaku khalayak yang bersangkutan
Banyak tujuan pemilih media massa disimpulkan dari data yang diberikan khalayak, artinya orang dianggap cukup mengerti untuk melaporkan kepentingan dan motif pada situasi-situasi tertentu.

Penilaian tentang arti kultural dari media massa harus ditangguhkan sebelum diteliti lebih dahulu orientasi khalayak.

McQuail (2011) memandang media sebagai pelayanan atas kebutuhan masyarakat yang beragam. Siswa sebagai pengguna internet menunjukan ciri sebagai pengguna aktif dan selektif dalam menggunakan smartphone sesuai dengan kebutuhan dan keinginan masing-masing. Mereka telah mampu menggunakan smartphone untuk memenuhi berbagai kebutuhan (uses) seperti kebutuhan informasi, kebutuhan komunikasi dan kebutuhan pendidikan. Mereka juga telah mampu menggunakan smartphone untuk mendapatkan kepuasan (gratifications).

\section{KESIMPULAN DAN SARAN}

Berdasarkan hasil penelitian dan pembahasan, maka kesimpulan pada penelitian ini adalah sebagai berikut:

Sebagian besar responden kurang aktif menggunakan smartphone. Hasil penelitian menunjukkan bahwa siswa yang dikategorikan rendah sebanyak 368 siswa $(56,9 \%)$ dari total responden 647 siswa (sekolah yang mengizinkan menggunakan smartphone sebanyak 343 siswa dan sekolah yang tidak mengizinkan menggunakan smartphone sebanyak 304 siswa).

Prestasi belajar siswa untuk sekolah yang mengizinkan penggunaan smartphone lebih tinggi dibandingkan tingkat prestasi yang tidak mengizinkan penggunaan smartphone di lingkungan sekolah

Hasil penelitian menunjukkan bahwa hubungan intensitas penggunaan smartphone dengan prestasi belajar siswa sekolah yang mengizinkan dan tidak mengizinkan penggunaan smartphone diperoleh nilai koefisien regresi bernilai positif. Artinya, semakin tinggi intensitas penggunaan smartphone, semakin tinggi prestasi belajar siswa. Sebaliknya, semakin rendah intensitas penggunaan smartphone, semakin rendah pula prestasi belajar siswa.

Berdasarkan kesimpulan diatas, maka penulis memberikan saran sebagai berikut: 
Peneliti menyarankan kepada pihak terkait, yaitu guru, pihak sekolah dan pemerintah agar senantiasa bersinergi dalam setiap upaya memaksimalkan penggunaan smartphone di lingkungan sekolah dengan memberikan kepada siswa sehingga dapat meningkatkan prestasi belajar siswa.

Kepada siswa SMAN 1 Kendari dan SMAN 4 Kendari secara khusus dan seluruh siswa secara umum yang diizinkan menggunakan smartphone oleh pihak sekolah,

\section{DAFTAR PUSTAKA}

\section{Buku}

Abdulhak, dkk. 2013. Teknologi Pendidikan. Bandung: PT Remaja Rosdakarya.

Ahmadi (1998). Faktor yang Mempengaruhi Belajar. Jakarta: PT Raja Grafindo Persada

Alexis.S, Tan. 1981. Pengantar Teori \& Manajemen Komunikasi. Jakarta: Jurnal Press.

Aridianto, Elvinaro dan Lukiati komala, 2007. Komunikasi Massa Revisi. Bandung: Simbiosa Rekatama Media.

Arikunto, S. 2006. Prosedur Penelitian Suatu Pendekatan Praktik. Jakarta: Rineka Cipta

Anthony, Giddens. 1982. Sociology; A Brief but Critical Introduction. New York: Harcourt Brace Jovanovich.

Bagdakian, Ben H. 2004. The New Media Monopoly. Boston: Beacon Press.

Bartlett, F.C. 1932. Remembering. Cambridge: Cambridge University Press.

Cangara, Hafied. 2014. Perencanaan dan Strategi Komunikasi. Jakarta: Rajawali Press.

Creeber, G and Martin, R. 2009. Digital Cultures: Understanding New Media. Berkshire-England: Open University Press.

Depari. 1991. Peranan Komunikasi Massa Dalam Pembangunan. Yogyakarta: Gadjah Mada University Press.

Effendy, Onong Uchjana. 1993. Ilmu, Teori \& Filsafat Komunikasi. Bandung: PT. Citra Aditya Bakti manfaatkanlah sebaik-baiknya untuk kepentingan pembelajaran sehingga dapat meningkatkan prestasi belajar anda.

Selain itu, kepada para pembaca, peneliti menyarankan bahwa hasil temuan dalam penelitian ini dapat dijadikan rujukan untuk melakukan penelitian lebih lanjut.

Harmin, M. 2012. Pembelajaran Aktif yang Menginspirasi. Jakarta: Indeks

Heeter, Carrie. 1988. Communications and Information Science Series. New york: Ablex Publishing.

Istiyanto, J. E. 2013, Pemrograman Smartphone menggunakan SDK Android dan Hacking Android. Yogyakarta: Graha Ilmu.

Kriyantono, Rachmat. 2010. Teknik Praktis Riset Komunikasi. Jakarta: Prenadamedia Group.

Liao, Kun-Hsi. 2012. Service Quality and Customer Satisfaction: Direct and Indirect Effects in a B2B Customer Loyalty Framework. Journal of Global Business Management Vol. 8.

Lievrouw, L.A. 2011. Alternative and Activist New Media. Cambridge: Polity Press.

Lievrouw, L.A. dan Sonia, Livistone. 2006. The Handbook of New Media. London: SAGE Publications.

Littlejohn, Stephan W. 2000. Theories of Human Communication. USA: Wadsworth Publishing Company

Margono. 2004. Metodologi Penelitian Pendidikan. Jakarta: Rineke Cipta

McQuail, Dennis. 2009. Mass Communication Theory. London: Stage Publication, Ltd

Miarso, Yusufhadi. 2007. Menyemai benih teknologi pendidikan. Jakarta: Pustekom Diknas.

Mustikoweni. 2002. Regresi dan Korelasi, Makalah Penataran Penelitian dan Statistik, Kopertis VII 
Mondry. 2008. Pemahaman Teori dan Praktik Jurnalistik. Bogor: Ghalia Indonesia.

Onong, Uchjana. 2003. Ilmu, TeoridanFilsafatKomunikas. Bandung: PT Citra Aditya

Paul, Siparno. 1996. Konstruktivisme dan Dampak terhadap Pendidikan. Kompas.

Piaget, Jean, \& Barbel Inhelder. 2010. Psikologi Anak, terjemahan Miftahul Jannah. Yogyakarta: Pustaka Pelajar.

Poedjiadi, Anna. 1999. Pengantar Filsafat Ilmu bagi Pendidik. Bandung: Penerbit Yayasan Cendrawasih.

Raka Joni, T. 1985. Strategi Belajar-Mengajar, Suatu Tujuan Pengantar. Jakarta: P2LPTK Depdikbud.

Rakhmat, Jalaluddin. 1991. Metode Penelitian Komunikasi. Bandung: PT Remaja Rosdakarya.

Ruben, Brent. 1998. Communication and Human Behavior. USA: Viacom Company.

Sugiyono. 2009. Metode Penelitian Bisnis (Pendekatan Kuantitatif, Kualitatif, dan R\&D). Bandung: Alfabeta.

2011. Metode penelitian kuantitatif, kualitatif dan R\&D. Bandung: Alfabeta.

Sukardi, 2012. Metodologi Penelitian Pendidikan. Jakarta: Bumi Aksara.

Surip, Muhammad. 2011. Teori Komunikasi: Perspektif Teoritis Teori Komunikasi. Medan: UNIMED.

Unde, Andi Alimuddin. 2014. Televisi dan Masyarakat Pluralistik. Jakarta: Prenadamedia Group.

Van Dijk. J.A.G.M. 2006. The Network Society. London: SAGE Publications.

\section{Skripsi}

Anggriamurti, R.A. 2009. Pembelajaran Transformasi Geometri dengan Pendekatan Kontruktivis untuk Meningkatkan Penalaran Logis Siswa Kelas XII SMA BPI 2 Bandung. Skripsi UPI: Tidak diterbitkan.

\section{Jurnal}

Setyani, Novia Ika, 2013. Penggunaan Media Sosial Sebagai Sarana Komunikasi Bagi
Komunitas. Jurnal Komunikasi

Universitas Sebelas Maret,(Online),

(http://digilib.uns.ac.id/pengguna.php?m $\mathrm{n}=$ detail\&d_id=31514. Diakses pada hari Senin, 13 Februari 2017).

Zuhaira Laily Kusuma, Subkhan, 2014.

Pengaruh Motivasi Belajar dan

Kedisiplinan Belajar terhadap Prestasi

Belajar Mata Pelajaran Akuntansisiswa

Kelas Xi Ips Sma N 3 Pati

Tahun Pelajaran 2013/2014, (https://www.scribd.com/doc/29070657

1/jurnal-prestasi-belajar-10-pdf.

Diakses pada hari kamis, 26 Oktober 2017).

Aldi Atwinda Jauhar, Nurist Surayya Ulfa, Tandiyo Pradekso, dan Agus Naryoso, 2015. Pengaruh Intensitas Penggunaan Smartphone dan Komunikasi Orangtua Anak Terhadap Prestasi Belajar Anak. Jurnal Komunikasi Universitas Diponegoro, (http://ejournal3.undip.ac.id/index.php/i nteraksionline/article/viewFile/8866/861 6. Diakses 27 Oktober 2017).

\section{Situs Berita dan Internet}

https://id.wikipedia.org/wiki/Media_sosial (diakses, senin 13 februari 2017). https://www.facebook.com/notes/wisnuiray/pengertian-social-media-socialnetwork-peran-sertafungsinya/10151963078035205/ (diakses, senin 13 februari 2017)

http://tita7ezer.blogspot.co.id/ (diakses, rabu 15 februari 2017)

https://www.scribd.com/doc/95232373/Skripsi -Penelitian-Tentang-Pengaruh-InternetTerhadap-Pelajar (diakses, Rabu 15 Februari 2017).

http://elizabelfri.blogspot.co.id/2013/05/teknol ogi-komunikasi-baru-smartphone.html (diakses, rabu 15 februari 2017)

http://inet.detik.com/consumer/d2485920/indonesia-masuk-5-besarnegara-pengguna-smartphone (diakses, 15 februari 2017)

http://idayoce.blogspot.co.id/2016/07/teoribelajar-konstruktivisme.html (diakses, kamis 16 februari 2017) http://mongonsidi48.blogspot.co.uk/201 
5/02/teori-dependensi-media-theory-ofmedia.html (diakses, selasa 31 Oktober 2017). 


\section{DAFTAR TABEL}

Tabel 4.1. Distribusi Responden berdasarkan nilai mean, median, Mode dan Range Intensitas Penggunaan Smartphone (Sumber: Data SPSS diolah 2017)

\begin{tabular}{lll}
\hline $\mathrm{N}$ & Valid & 647 \\
\cline { 2 - 3 } & Missing & 0 \\
\hline Mean & 35.88 \\
Median & 37.00 \\
Mode & 35 \\
Range & 41 \\
Minimum & 11 \\
Maximum & 52 \\
\hline
\end{tabular}

Tabel 4.2. Distribusi Responden Berdasarkan Variabel Kepemilikan Smartphone (Sumber: Data SPSS diolah 2017)

\begin{tabular}{lll}
\hline \multirow{2}{*}{ Variabel Penelitian } & Frekuensi \\
\cline { 2 - 3 } & $\mathrm{n}(647)$ & $\%$ \\
\hline tidak memiliki smartphone dan jaringan & 147 & 22,7 \\
memiliki smartphone dan jaringan & 500 & 77,3 \\
\hline
\end{tabular}

Tabel 4.3. Distribusi Responden Berdasarkan Variabel Intensitas Penggunaan Smartphone (Sumber: Data SPSS diolah, 2017)

\begin{tabular}{lll}
\hline \multirow{2}{*}{ Variabel Penelitian } & Frekuensi & \\
\cline { 2 - 3 } & $\mathrm{n}(647)$ & $\%$ \\
\hline Tinggi & 279 & 43,1 \\
Rendah & 368 & 56,9 \\
\hline
\end{tabular}

Tabel 4.4. Distribusi Responden Berdasarkan Variabel Kelompok Sekolah (Sumber: Data SPSS diolah 2017)

\begin{tabular}{lll}
\hline \multirow{2}{*}{ Variabel Penelitian } & Frekuensi \\
\cline { 2 - 3 } & $\mathrm{n}(647)$ & $\%$ \\
\hline Tidak mengizinkan & 304 & 47 \\
Mengizinkan & 343 & 53 \\
\hline
\end{tabular}

Tabel 4.5. Distribusi Responden berdasarkan Prestasi Belajar Siswa (Sumber: Data SPSS diolah 2017)

\begin{tabular}{lll}
\hline \multirow{2}{*}{$\mathrm{N}$} & Valid & 647 \\
\cline { 2 - 3 } & Missing & 0 \\
\hline Mean & & 85.00 \\
Median & & 85.00 \\
Mode & 90 \\
Range & 33 \\
Minimum & 61 \\
Maximum & 94 \\
\hline
\end{tabular}


Tabel 4.6. Distribusi Responden Berdasarkan Tingkat Prestasi Siswa (Sumber: Data SPSS diolah 2017)

\begin{tabular}{lll}
\hline \multirow{2}{*}{ Variabel Dependen } & Frekuensi & \\
\cline { 2 - 3 } & $\mathrm{n}(647)$ & $\%$ \\
\hline Rendah & 266 & 41,1 \\
Tinggi & 381 & 58,9 \\
\hline
\end{tabular}

Tabel 4.7. Analisis regresi linear sederhana (Model Summary)

\begin{tabular}{l|l|l|l|l}
\hline & & & & \\
Model & R & R Square & Adjusted R Square & Std. Error of the Estimate \\
\hline 1 & $.409 \mathrm{a}$ & .168 & .166 & .450 \\
\hline
\end{tabular}

a. Predictors: (Constant), intensitas

Tabel 4.8. Analisis regresi linear sederhana (Anova)

\begin{tabular}{l|l|l|l|l|l}
\hline Model & $\begin{array}{l}\text { Sum of } \\
\text { Squares }\end{array}$ & Df & Mean Square & F & Sig. \\
\hline $\begin{array}{l}1 \quad \text { Regression } \\
\text { Residual }\end{array}$ & 26.250 & 1 & 26.250 & 129.851 & $.000 \mathrm{a}$ \\
Total & 130.390 & 645 & .202 & & \\
\hline
\end{tabular}

a. Predictors: (Constant), intensitas

b. Dependent Variable: tingkat prestasi

Tabel 4.9. Analisis regresi linear sederhana (Coefficients)

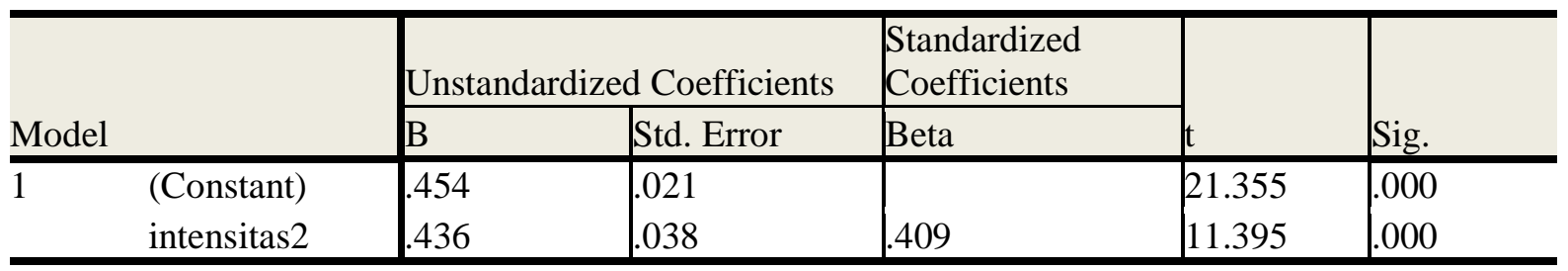

a. Dependent Variable: tingkat prestasi

Tabel 4.10. Analisis Uji T (Independent Samples Test)

\begin{tabular}{|c|c|c|c|c|c|c|c|c|c|c|}
\hline & \multicolumn{2}{|c|}{\begin{tabular}{|l|} 
Levene's Test \\
for Equality of \\
Variances \\
\end{tabular}} & \multicolumn{7}{|c|}{ t-test for Equality of Means } \\
\hline & & \multirow[b]{2}{*}{$F$} & \multirow[b]{2}{*}{ Sig. } & \multirow[b]{2}{*}{$T$} & \multirow[b]{2}{*}{ Df } & \multirow{2}{*}{\begin{tabular}{|l} 
Sig. \\
$(2-$ \\
tailed $)$
\end{tabular}} & \multirow{2}{*}{$\begin{array}{l}\text { Mean } \\
\text { Difference }\end{array}$} & \multirow[t]{2}{*}{$\begin{array}{l}\text { Std. Error } \\
\text { Difference }\end{array}$} & \multicolumn{2}{|c|}{$\begin{array}{l}95 \% \\
\text { Confidence } \\
\text { Interval of the } \\
\text { Difference }\end{array}$} \\
\hline & & & & & & & & & Lower & Upper \\
\hline \multirow[t]{2}{*}{$\begin{array}{l}\text { Prestasi } \\
\text { belajar }\end{array}$} & $\begin{array}{l}\text { Equal } \\
\text { variances } \\
\text { assumed }\end{array}$ & 116.363 & .000 & 27.651 & 645 & .000 & .726 & .026 & .675 & .778 \\
\hline & $\begin{array}{l}\text { Equal } \\
\text { variances not } \\
\text { assumed }\end{array}$ & & & 26.946 & 500.492 & .000 & .726 & .027 & .673 & .779 \\
\hline
\end{tabular}

